\title{
FORMAÇÃO INTERDISCIPLINAR
}

\author{
Prof. Dr. Renato Janine RIBEIRO**
}

Há várias maneiras de pensar a colaboração interdisciplinar, quer na pesquisa, quer na docência universitária. Mas é evidente que, num tempo como o nosso, uma mesma pessoa dominar várias áreas do saber - e portanto reunir em si quatro ou cinco disciplinas - se tornou quase impossível. É isso então o que leva muitos a entender que a interdisciplinaridade só pode ser um trabalho coletivo, no qual especialistas de áreas distintas se reúnem. Não haverá, portanto, um pesquisador interdisciplinar; haverá, sim, grupos de diálogo e discussão.

Essa posição está certa, mas não por inteiro. Porque, se o enfoque interdisciplinar for apenas o de uma associação de cientistas, ele será muito tímido. $\mathrm{O}$ que o diálogo entre as ciências ou saberes pode trazer é bem mais que isso: é a eventual renovação, ou revolução, de áreas que estão marcando passo. O grande exemplo histórico de que dispomos, a este respeito, é o da geometria. Desde o momento em que Euclides a criou até o século XVII, passaram-se mais de dois mil anos; e foi nesta última data, nos inícios da modernidade, que ela, até então um instrumento competente, mas limitado, restrito à mensuração da terra e dos espaços, se converteu em paradigma das ciências. Para tanto, foi preciso retirar a geometria de seu canto e lançá-la no centro do pensamento. É claro que assim se tornou pouco importante que ela medisse terrenos: o que contou foi o grau de verdade, a elegância da demonstração, o caráter irrefutável de suas provas. Valeu mais sua forma, sua posição, do que seu conteúdo, sua produção imediata. Mas não houve, na história das ciências, revolução igual a essa.

Há casos análogos. Georges Duby, um dos maiores medievalistas de nossos tempos, em seu Guilherme Marechal - o melhor cavaleiro do mundo (ed. Graal), afirma a certa altura que a história das mentalidades - da qual esse livro constitui excelente amostra - não é senão etnologia. A antropologia e as disciplinas a ela anexas tiveram assim, nas últimas décadas, papel essencial na renovação das ciências humanas, em especial da história. E por sinal a história aprendeu muito com as ciências sociais em geral, bem como com a economia.

Isso significa que o diálogo não pode ser apenas externo entre as ciências. É útil, mas insuficiente, um historiador conversar com um antropólogo. É preciso, isso sim, cada um entender algo do olhar do outro. Tenho pensado como seria interessante, num curso de ciências sociais, propor que assuntos característicos de uma das ciências sejam estudados sob o enfoque

* Transcrito do Jornal da Universidade- UFRGS, abril, 2002.

** Professor titular de Ética e Filosofia Política do Departamento de Filosofia da Universidade de São Paulo. 
de outra. Por exemplo, tribos constituem reserva da antropologia. Mas o que acontecerá se cientistas políticos e sociólogos as estudarem?

$\mathrm{Ou}$ : estamos acostumados a ler, nos primeiros cadernos dos jornais, as opiniões dos cientistas políticos sobre as eleições. Quando especialistas de outras áreas - por exemplo, de filosofia política - são consultados, as perguntas que nos colocam são praticamente as mesmas que vão para os cientistas políticos. Assim a pauta do caderno Brasil destaca o cientista político, a do caderno Cidades ou Geral abre-se para o sociólogo, especialmente quando se fala da violência e da miséria, e os antropólogos vão para o caderno de Cultura ou Variedades. Mas, se embaralharmos tudo isso? Chamemos os antropólogos a tratar das candidaturas, mas não clonando a linguagem dos politólogos, e sim em seu próprio enfoque. Convidemos o sociólogo a tratar de política nacional e de artes - o que alguns fazem, mas é raro. $\mathrm{O}$ resultado pode ser interessante, mesmo quando der errado. É claro que não se espera que o leigo acerte num assunto melhor que o especialista. Contudo, minha sugestão não é apenas de um recurso didático que torne mais animadas as aulas (como cada ciência examina o mesmo tema, o mesmo assunto?), mas a de uma abertura às surpresas que podem vir, para o pesquisador, da adoção de um instrumental pouco usual. O mais das vezes a experiência dará errado, mas basta que produza uma real novidade em alguns casos para que valha a pena.

Mais que isso: levemos a sério a expressão "troca de pontos de vista", usada para definir o diálogo entre diferentes. Não deve significar só que cada um defina seu olhar. Deve significar que permutemos nossos olhares, que por um tempo enxerguemos o mundo com um óculo emprestado. E isso significa reforçar, no ensino e na pesquisa, o lugar da imaginação. Uma das maiores qualidades da matemática, que um adolescente percebe quando lhe ensinam bem os teoremas, é o papel da imaginação para encontrar soluções. Contudo, o ensino tende, o mais das vezes, a sacrificar a imaginação no altar de um espírito de seriedade. Explorar saídas alternativas acaba ficando menos importante do que trilhar caminhos já consagrados. E é por isso que no projeto de curso interdisciplinar de graduação em Humanidades, que estou organizando na Universidade de São Paulo (ver Humanidades, um novo curso na USP, Edusp, 2001), um intenso recurso à filosofia, à literatura e às artes pretende dar ao aluno uma pluralidade de perspectivas. $\mathrm{O}$ mundo está em mudança, e devemos testar nossos olhos em objetos pouco praticados. 